\title{
First report of the infection of alfalfa mosaic virus in Salvia sclarea in Hungary
}

\author{
Pal Salamon ${ }^{1} \cdot$ Anita Sos-Hegedus $^{1} \cdot$ Peter Gyula $^{1} \cdot$ Gyorgy Szittya ${ }^{1,2}$
}

Published online: 11 July 2018

(C) Società Italiana di Patologia Vegetale (S.I.Pa.V.) 2018

In summer 2016 bright yellow mosaic symptoms were detected in plants of wild growing populations of Salvia sclarea L. (clary sage) near Lake Velencei (Middle-West Hungary). Similar symptoms caused by alfalfa mosaic virus (AMV) infections were reported earlier affecting clary sage in Italy and Bulgaria (Bellardi et al. 1999; Dikova 2014).

Inoculation of test plants with extracts of diseased clary sage leaves demonstrated the presence of a mechanically transmitted plant virus named isolate Ssc. The Ssc isolate caused mild mosaic in Nicotiana clevelandii, $N$. glutinosa and N. tabacum cv. Xanthi-nc, reddish necrotic lesions in Vigna sinensis, and systemic necrosis in Chenopodium quinoa. Ocimum basilicum plants reacted with bright yellow mosaic (calico) symptoms. All of the reactions of test plants, especially those of $O$. basilicum strongly suggested the infection with alfalfa mosaic virus (AMV).

For molecular characterization, RT-PCR primers were designed based on the consensus sequence of five different AMV CP gene sequences. Total nucleic acid was isolated from symptomatic leaves of inoculated tobacco plants, and RT-PCR was carried out using the forward primer
(5'-TGGTGGGAAAGCTGGTAAAC-3') and reverse primer (5'-TCTCTCGACCCAAACTTCGT-3'). The PCR product of expected size (559 bp) was cloned and sequenced, and the sequence was deposited in GenBank (KY860733). Blast analysis showed a nucleotide sequence homology of $99 \%$ with the CP genes of other AMV isolates. The presence of the virus in Salvia sclarea was confirmed by Northern blot using the cloned PCR product as a probe. Based on bioassay and molecular studies, the virus was identified as isolate Ssc of AMV. This is the first report of the natural infection of $S$. sclarea by AMV in Hungary.

Acknowledgements This work was supported by Hungarian National Research, Development and Innovation Office grant K-119701.

\section{References}

Bellardi MG, Autonell CR, Bertaccini A (1999) Virus and phytoplasma infections on officinal plants in Emilia-Romagna. Informatore Fitopatologico 49:47-53

Dikova B (2014) Establishment of virus pathogens on the medicinal plant Salvia sclarea. Sci Technol 4:15-22
Gyorgy Szittya

szittya.gyorgy@abc.naik.hu

1 Agricultural Biotechnology Institute, National Agricultural Research and Innovation Centre, Gödöllö, Hungary

2 Institute of Plant Biotechnology, Agricultural Biotechnology Institute, National Agricultural Research and Innovation Centre, Szent-Györgyi Albert út 4, Gödöllő H-2100, Hungary 